\title{
EVALUATION OF SEVERAL LESS KNOWN PEAR (Pyrus communis L.) CULTIVARS IN THE CLIMATIC CONDITIONS OF LOWER SILESIA
}

\author{
Ireneusz Sosna, Daria Kortylewska \\ Department of Horticulture, Wroclaw University of Environmental and Life Sciences \\ pl. Grunwaldzki 24 A, 50-363 Wrocław, Poland \\ e-mail: ireneusz.sosna@up.wroc.pl
}

Received: 23.04.2012

\begin{abstract}
The aim of this study was to evaluate flowering, yielding, fruit quality, and growth of several less known pear cultivars growing in the climatic conditions of Lower Silesia. The experiment was conducted in the years 2006-2010 in the Fruit Experimental Station located in Samotwór near Wrocław. In spring 2006, trees of several less known pear cultivars were planted: 'Isolda', 'Hortensia', 'Fertilia Delbard Delwilmor', 'Wyżnica', 'Nojabrskaja' ('Xenia ${ }^{\circledR}$ '), 'Uta', 'David' on Caucasian pear (Pyrus caucasica Fed.), 'Bohemica' on quince S1 (Cydonia oblonga Mill.) as well as 'Morava' and 'Blanka' on both these rootstocks. The highest total yield in the years 2007-2010 was recorded for the 'Nojabrskaja' and 'Wyżnica' cultivars. The 'Blanka' cultivar produced the largest fruit, while fruits of the 'Isolda' cultivar were significantly the smallest. The largest growth and cross-sectional area of the trunk were recorded for the trees of the 'Wyżnica' cultivar, while the smallest were observed in the case of 'Morava', in which the thickness of the trunk was similar on both rootstocks. The 'Morava' cultivar grafted on quince S1 formed the smallest crowns. On the other hand, 'Isolda' and 'Hortensia' were among the cultivars that produced the largest crowns.
\end{abstract}

Key words: pear, cultivar, rootstock, yield, quality, flowering, growth

\section{INTRODUCTION}

The pear tree has higher climate and soil requirements than the apple tree. It is cultivated in countries with a warm climate, such as Italy, Spain, China, Argentina, and Chile. (S o sna, 2007; Mohan Jain and Priy adarshan, 2009). In Poland, the range of its cultivation ends in the central part of the country, because the farther north, the climate is less favourable. The establishment of new and intensive pear orchards is limited to a large extent by low availability of rootstocks that grow slowly and are resistance to frost (B i e li cki and C zy n c zyk, 2006; B i e li c$\mathrm{ki}$ et al. 2010). Selected clones of quince can inhibit the growth of trees from 30 to $60 \%$ as compared with trees grafted on Caucasian pear seedlings (K v i k l y s, 2005; Castro and Rodríguez, 2007; S tern et al. 2007). Some clones of quince are not sufficiently resistant to low temperatures and exhibit physiological incompatibility with certain pear cultivars (Bielicki et al. 2010). Rootstocks derived from quince speed up entering into the fruit-bearing stage by trees, increase their yield efficiency, and have a beneficial influence on fruit size (Kviklys and Kviklien , 2005). A slight increase in the production of pears does not satisfy the needs of consumers, because such fruits are not available in the winter season or are too expensive. Also the selection of cultivars is limited. For many years, only three cultivars have been leading the way in cultivation of commodity crops: 'Konferencja', 'Faworytka' and 'Lukasówka'. In recent years, there have appeared new, late-ripening cultivars with attractive fruits, which can be stored in good conditions for a long period. There is also a growing interest in summer pear trees with fruits ripening before 'Faworytka', as well as in cultivars with red-tinted peel ( $\mathrm{S}$ o s n a, 2007). It is reasonable to introduce the new cultivars to production and, first of all, to check their suitability for cultivation (B i e li cki and C zy n c z y k, 2006).

The aim of this study was to evaluate flowering, yielding, fruit quality, and the vegetative growth of several less known pear cultivars growing in the climatic conditions of Lower Silesia.

\section{MATERIALS AND METHODS}

The experiment was conducted in the years 2006-2010 in the Fruit Experimental Station located in 
the village of Samotwór near Wrocław. In spring 2006, trees of several less known pear (Pyrus communis L.) cultivars were planted: 'Isolda', 'Hortensia', 'Fertilia Delbard Delwilmor', 'Morava', 'Wyżnica', 'Nojabrskaja' ('Xenia ${ }^{\circledR}$ '), 'Blanka', 'Uta', 'David' and 'Bohemica'. The 'Bohemica' cultivar was planted on quince S1 (Cydonia oblonga Mill.), 'Morava' and 'Blanka' - on quince S1 and Caucasian pear, and the other cultivars, due to the lack of explicit information as to the compatibility on quince clones, only on Caucasian pear (Pyrus caucasica Fed.). Trees were planted at a spacing of $3.5 \times 1.5 \mathrm{~m}$ (1905 trees/ha), except for the 'Bohemica', 'Blanka' and 'Morava' cultivars, for which the spacing of $3.5 \times 1.2 \mathrm{~m}$ was used. The pear trees were kept in the form of a spindle crown. Until the third year after planting, the growing shoots were mainly bent, and from the fourth year, pruning was performed after flowering in May. Herbicide fallow was maintained in tree rows, while in interrows - durable grass. The experiment was set up using a randomised block design with four replications, five trees per experimental plot.

In the years 2007-2008, an evaluation of flowering was performed on the basis of the number of inflorescences per tree. In the subsequent years, during the full bloom stage, the intensity of flowering was determined on each experimental tree in a six-grade scale, where 0 meant a tree that did not blossom, while 5 - very abundant blossoming. The dates of full flowering and the time of harvesting were given for the examined cultivars. An evaluation of yielding was performed for all the trees in the subsequent years of the study. In order to determine an average weight of the fruit from each experimental tree, 20 specimens of randomly selected fruits were weighed per tree. Biometric measurements were performed of the above-ground part (diameter), and from the $4^{\text {th }}$ year - measurements of the trunk circumference, the number and length of one-year shoots as well as the height and range of the crown. The results of these measurements were used for evaluating the tree growth of the examined pear cultivars. The yield efficiency index, which is the ratio of the sum of the yields from the years to the cross-sectional area of the trunk, was also calculated in the last year of the study.

The results were analysed statistically using the ANOVA method (analysis of variance) for the randomised blocks. When assessing the significance of differences between means, Duncan's test at the significance level $=0.05$ was used.

\section{RESULTS AND DISCUSSION}

In the second year after planting the trees, 'Hortensia' and 'David' had the largest number of flowers, while 'Wyżnica', 'Nojabrskaja', 'Uta' and 'Bohemica' pear trees did not bloom at all (Table 1). In the subsequent year, the number of inflorescences varied. Their highest number was observed on trees of the 'Nojabrskaja' and 'Blanka'/Q1 cultivars. 'Uta' and 'Morava'/ PCs pear trees bloomed very poorly and formed few inflorescences. In 2009 the majority of cultivars blossomed with a medium intensity, except for 'Isolda' and 'Bohemica' pear trees, which bloomed poorly. In the $5^{\text {th }}$ year of the experiment, the 'Nojabrskaja', 'Bohemica' and 'Blanka' cultivars on Caucasian pear and on quince were characterised by the highest intensity of flowering, while 'Hortensia' pear tree - by the lowest. In the first five years of the study, a tendency towards alternation of flowering and fruiting was observed in 'Hortensia' trees.

The earliest flowering cultivars included 'Nojabrskaja', 'Blanka' and 'David', while 'Isolda', 'Fertilia Delbard Delwilmor', 'Wyżnica' and 'Bohemica' belonged to the group of cultivars that bloomed latest (Table 2). The fruits of the examined cultivars were harvested from August to the first decade of October. The 'Isolda' pear tree reached the harvest maturity in early August. Fruit of the 'Uta', 'David' and 'Bohemica' cultivars ripened as the latest.

In the second year after planting, a low yield was obtained only from trees of the 'Hortensia', 'Fertilia Delbard Delwilmor' and 'Morava'/Q1 cultivars (Table $3)$. All cultivars produced fruit already since 2008 . The significantly highest number of fruits was harvested from the 'Nojabrskaja' pear trees. Very low yielding, below $1 \mathrm{~kg}$ of fruit per tree, was recorded for the 'Morava'/PCs, 'Blanka', 'Uta' and 'Isolda' cultivars. Higher yields were obtained in 2009. The 'Hortensia', 'Fertilia Delbard Delwilmor', 'Uta', 'Wyżnica' and 'Nojabrskaja' cultivars produced the highest number of fruits. In the spring of 2010 , frost $\left(-4^{\circ} \mathrm{C}\right)$ occurred on the night of $22^{\text {th }}-23^{\text {th }}$ April and it damaged most strongly buds and flowers of the 'Fertilia Delbard Delwilmor', 'Isolda', 'Nojabrskaja' and 'David' cultivars. Therefore, the harvested yield was lower than in the previous year, except for the 'Blanka' and 'Bohemica' cultivars. According to Kurlus and $€$ y s i ak (1999), the 'Bohemica' cultivar was characterized by abundant fruiting each year, which was not confirmed by the author's own studies. The highest total yield in the years 20072010 was recorded for the 'Nojabrskaja' and 'Wyżnica' cultivars. B i e li c k i et al. (2008) obtained similar results with the 'Nojabrskaja' cultivar. He i j er m a n-P e p pe $1 \mathrm{~m}$ a n et al. (2009) also found that this Moldovan cultivar started fruiting quite early and gave high yield. In the author's own studies, the 'David' cultivar was characterized by average yield efficiency. In turn, B l a ž e k et al. (2003) as well as Paprštein and 
Kloutvor (2005a) showed in their experiments that this pear cultivar is one of the most productive.

Based on the results of the 5-year study, it can be stated that 'Blanka'/PCs and 'Isolda' belonged to the group of cultivars with the lowest yield efficiency. On the other hand, P a pršte in et al. (2007) found in their studies that the summer pear cultivar 'Isolda' was characterized by medium yield efficiency. No statistical differences in total yield were observed depending on the rootstock used for the 'Morava' cultivar. On the other hand, the trees of the 'Blanka' cultivar grafted on quince $\mathrm{S} 1$ yielded significantly better than on Caucasian pear. Other researchers ( $\mathrm{S}$ o s n a and Czaplicka, 2007; Le w ko and Modrak, 2009) obtained similar results. Trees of the 'Blanka' cultivar fruited poorly despite good blossoming each year. This could be caused by a lack of suitable pollinators or by the propensity for fruit setting only at an older age of trees. The average weight of one fruit was used for evaluating the fruit quality. Statistical differences were observed in the average weight of the fruit depending on the cultivar studied. The 'Blanka' cultivar produced the biggest pear fruits. The type of rootstock used had no significant effect on the size of fruits of the cultivars 'Blanka' and 'Morava', which was not confirmed by the Lithuanian studies. Kviklys and Kviklien (2005) showed that quince S1 had a favourable influence on the average weight of harvested pears. In the author's own studies, the 'Isolda' pear-tree had the smallest fruits; this is also reported by $\mathrm{P}$ a pr šte in and K1 ou tvor (2005b).

The trees of 'Wyżnica' had the largest cross-sectional area and two-year growth of the trunk, while the smallest were observed in the case of the cultivar 'Morava', in which the thickness of the trunk was similar on both rootstocks used (Table 4). The trees of the 'Blanka' cultivar were characterized by the strongest growth on Caucasian pear seedlings. They had the thickest trunks and the largest crowns. The results of the studies conducted by B i licki and $\mathrm{Czyn}$ c z y k (2006) confirm this finding. These researchers also established that pear trees growing on quince $\mathrm{S} 1$ were smaller by $63 \%$ as compared with those growing on Caucasian pear. In the present study, the cultivar 'Morava' grafted on quince S1 formed the smallest crowns. On the other hand, 'Isolda' and 'Hortensia' were among the cultivars with the largest crowns. The trees of the cultivars 'Isolda', 'David', 'Nojabrskaja' and 'Wyżnica' produced the largest number of one-year shoots. The largest total number of one-year shoots was observed in the 'David', 'Isolda' and 'Hortensia' cultivars. The pear tree 'Blanka' formed the least dense crowns. The highest yield efficiency index was observed in the case of poorly growing trees of the 'Uta', 'Nojabrskaja' and 'Fertilia Delbard Delwilmor' cultivars. The smallest number of fruits per $1 \mathrm{~cm}^{2}$ of the cross-sectional area of the trunk was observed in the case of the 'Blanka'/PCs and 'Isolda' cultivars.

Table 1

Flowering of the new pear cultivars evaluated (planting of tree - spring of 2006)

\begin{tabular}{|c|c|c|c|c|}
\hline \multirow{2}{*}{ Cultivar/rootstock } & \multicolumn{2}{|c|}{ Number of inflorescences per tree } & \multicolumn{2}{|c|}{ Blooming intensity in $0-5$ scale } \\
\hline & 2007 & 2008 & 2009 & 2010 \\
\hline 'Isolda'/CPS & $0.1 \mathrm{a}^{*}$ & $4.1 \mathrm{ab}$ & $1.5 \mathrm{a}$ & $2.1 \mathrm{ab}$ \\
\hline 'Hortensia'/CPS & $4.8 \mathrm{~b}$ & $14.9 \mathrm{ab}$ & $3.3 \mathrm{~cd}$ & $1.5 \mathrm{a}$ \\
\hline 'Fertilia'/CPS & $1.5 \mathrm{ab}$ & $7.9 \mathrm{ab}$ & $3.3 \mathrm{~cd}$ & $2.7 \mathrm{bc}$ \\
\hline 'Morava'/Q1 & $1.5 \mathrm{ab}$ & $13.8 \mathrm{ab}$ & $2.6 \mathrm{bc}$ & $2.9 \mathrm{c}$ \\
\hline 'Morava'/CPS & $0.3 \mathrm{a}$ & $1.8 \mathrm{a}$ & $2.5 \mathrm{bc}$ & $3.1 \mathrm{~cd}$ \\
\hline 'Wyżnica'/CPS & $0.0 \mathrm{a}$ & $18.6 \mathrm{ab}$ & $2.9 \mathrm{~b}-\mathrm{d}$ & $2.9 \mathrm{c}$ \\
\hline 'Nojabrskaja'/CPS & $0.0 \mathrm{a}$ & $75.5 \mathrm{~d}$ & $3.5 \mathrm{~d}$ & $3.4 \mathrm{c}-\mathrm{e}$ \\
\hline 'Blanka'/Q1 & $1.8 \mathrm{ab}$ & $54.0 \mathrm{~cd}$ & $3.4 \mathrm{~d}$ & $4.1 \mathrm{e}$ \\
\hline 'Blanka'/CPS & $3.0 \mathrm{ab}$ & $29.8 \mathrm{bc}$ & $3.1 \mathrm{~cd}$ & $3.9 \mathrm{e}$ \\
\hline 'Uta'/CPS & $0.0 \mathrm{a}$ & $0.8 \mathrm{a}$ & $2.5 \mathrm{bc}$ & $3.0 \mathrm{~cd}$ \\
\hline 'David'/CPS & $4.7 \mathrm{~b}$ & $14.8 \mathrm{ab}$ & $2.8 \mathrm{~b}-\mathrm{d}$ & $2.7 \mathrm{bc}$ \\
\hline 'Bohemica'/Q1 & $0.0 \mathrm{a}$ & $2.9 \mathrm{a}$ & $2.1 \mathrm{ab}$ & $3.7 \mathrm{de}$ \\
\hline
\end{tabular}

* Means followed by the same letter do not differ at $\mathrm{p}=0.05$ according to Duncan's multiple range t-test CPS - Caucasian pear seedling, Q1 - Ouince S1 
Table 2

Date of full bloom and harvest time of the new pear cultivars evaluated

\begin{tabular}{|c|c|c|c|c|c|c|}
\hline \multirow{2}{*}{ Cultivar/rootstock } & \multicolumn{3}{|c|}{ Full bloom date (day/month) } & \multicolumn{3}{|c|}{ Harvest time (day/month) } \\
\hline & 2008 & 2009 & 2010 & 2008 & 2009 & 2010 \\
\hline 'Isolda'/CPS & 25.IV & 21-22.IV & 26.IV & 1.VIII & 6.VIII & 10.VIII \\
\hline 'Hortensia'/CPS & 24.IV & 21-22.IV & 24.IV & 15.IX & 15.IX & 20.IX \\
\hline 'Fertilia'/CPS & 25.IV & 23.IV & 26.IV & 15.IX & 15.IX & 20.IX \\
\hline 'Morava'/Q1 & 23.IV & 21.IV & 24.IV & 21.IX & 28.IX & 24.IX \\
\hline 'Morava'/CPS & - & 21.IV & 24.IV & 21.IX & 28.IX & 24.IX \\
\hline 'Wyżnica'/CPS & 25.IV & 23-24.IV & 26.IV & 23.IX & $2 . \mathrm{X}$ & 28.IX \\
\hline 'Nojabrskaja'/CPS & 19.IV & 20.IV & 21.IV & 23.IX & $2 . X$ & 28.IX \\
\hline 'Blanka'/Q1 & 20.IV & 20.IV & 21.IV & 23.IX & 2.X & 28.IX \\
\hline 'Blanka'/CPS & 21.IV & 20.IV & 22.IV & 23.IX & 2.X & 28.IX \\
\hline 'Uta'/CPS & - & 22.IV & 25.IV & $8 . \mathrm{X}$ & $8 . \mathrm{X}$ & $7 . \mathrm{X}$ \\
\hline 'David'/CPS & 21.IV & 20.IV & 21-22.IV & $8 . \mathrm{X}$ & $8 . \mathrm{X}$ & $7 . \mathrm{X}$ \\
\hline 'Bohemica'/Q1 & 24.IV & 22.IV & 26.IV & $8 . X$ & $8 . X$ & 7.X \\
\hline
\end{tabular}

Table 3

Yielding and mean fruit weight of the new pear cultivars evaluated

\begin{tabular}{|c|c|c|c|c|c|c|}
\hline \multirow{2}{*}{ Cultivar/rootstock } & \multicolumn{4}{|c|}{ Yield $\left[\mathrm{kg}\right.$ tree $\left.^{-1}\right]$} & \multirow{2}{*}{$\begin{array}{c}\begin{array}{c}\text { Cumulative yield } \\
{\left[\mathrm{kg}^{\mathrm{kgee}}{ }^{-1}\right]}\end{array} \\
2007-2010\end{array}$} & \multirow{2}{*}{$\begin{array}{c}\text { Mean fruit weight } \\
{[\mathrm{g}]} \\
2008-2010\end{array}$} \\
\hline & 2007 & 2008 & 2009 & 2010 & & \\
\hline 'Isolda'/CPS & $0.0 \mathrm{a}^{*}$ & $1.0 \mathrm{ab}$ & $4.3 \mathrm{a}-\mathrm{c}$ & $3.6 \mathrm{ab}$ & $8.9 \mathrm{ab}$ & $159 \mathrm{a}$ \\
\hline 'Hortensia'/CPS & $0.2 \mathrm{ab}$ & $2.6 \mathrm{bc}$ & $11.9 \mathrm{de}$ & $2.8 \mathrm{a}$ & $17.5 \mathrm{~d}$ & $231 \mathrm{~b}$ \\
\hline 'Fertilia'/CPS & $0.3 \mathrm{~b}$ & $3.7 \mathrm{c}$ & $12.1 \mathrm{e}$ & $2.0 \mathrm{a}$ & $18.1 \mathrm{~d}$ & $327 \mathrm{~cd}$ \\
\hline 'Morava'/Q1 & $0.2 \mathrm{ab}$ & $1.3 \mathrm{ab}$ & $5.0 \mathrm{bc}$ & $2.9 \mathrm{a}$ & $9.4 \mathrm{~b}$ & $335 \mathrm{~d}$ \\
\hline 'Morava'/CPS & $0.0 \mathrm{a}$ & $0.3 \mathrm{a}$ & $7.1 \mathrm{c}$ & $3.7 \mathrm{ab}$ & $11.1 \mathrm{bc}$ & $331 \mathrm{~cd}$ \\
\hline 'Wyżnica'/CPS & $0.0 \mathrm{a}$ & $3.3 \mathrm{c}$ & $13.6 \mathrm{e}$ & $12.8 \mathrm{~d}$ & $29.7 \mathrm{e}$ & $263 \mathrm{bc}$ \\
\hline 'Nojabrskaja'/CPS & $0.0 \mathrm{a}$ & $7.0 \mathrm{~d}$ & $14.2 \mathrm{e}$ & $9.9 \mathrm{~cd}$ & $31.1 \mathrm{e}$ & $290 \mathrm{~b}-\mathrm{d}$ \\
\hline 'Blanka'/Q1 & $0.0 \mathrm{a}$ & $0.7 \mathrm{a}$ & $5.0 \mathrm{bc}$ & $10.3 \mathrm{~cd}$ & $16.0 \mathrm{~cd}$ & $699 \mathrm{e}$ \\
\hline 'Blanka'/CPS & $0.0 \mathrm{a}$ & $0.5 \mathrm{a}$ & $0.6 \mathrm{a}$ & $2.4 \mathrm{a}$ & $3.5 \mathrm{a}$ & $656 \mathrm{e}$ \\
\hline 'Uta'/CPS & $0.0 \mathrm{a}$ & $0.5 \mathrm{a}$ & $12.2 \mathrm{e}$ & $8.4 \mathrm{~b}-\mathrm{d}$ & $21.1 \mathrm{~d}$ & $262 \mathrm{bc}$ \\
\hline 'David'/CPS & $0.0 \mathrm{a}$ & $1.4 \mathrm{ab}$ & $7.7 \mathrm{~cd}$ & $1.3 \mathrm{a}$ & $10.4 \mathrm{bc}$ & $243 \mathrm{~b}$ \\
\hline 'Bohemica'/Q1 & $0.0 \mathrm{a}$ & $1.3 \mathrm{ab}$ & $2.5 \mathrm{ab}$ & $5.4 \mathrm{a}-\mathrm{c}$ & $9.2 \mathrm{~b}$ & $244 \mathrm{~b}$ \\
\hline
\end{tabular}

* Explanations, see Table 1 
Table 4

Vegetative growth and crop efficiency coefficient (CEC) of the new pear cultivars evaluated

\begin{tabular}{|c|c|c|c|c|c|c|}
\hline \multirow{2}{*}{ Cultivar/rootstock } & \multicolumn{2}{|c|}{ Trunk cross-sectional area $\left[\mathrm{cm}^{-2}\right]$} & \multicolumn{2}{|c|}{$\begin{array}{l}\text { Annual shoots per tree }{ }^{-1} \\
\text { Total for } 2006-2008\end{array}$} & \multirow{2}{*}{$\begin{array}{c}\begin{array}{c}\text { Canopy volume } \\
{\left[\mathrm{m}^{3}\right]}\end{array} \\
\text { autumn } 2010\end{array}$} & \multirow{2}{*}{$\begin{array}{c}\text { CEC } \\
{\left[\mathrm{kg} \mathrm{cm}^{-2}\right]}\end{array}$} \\
\hline & autumn 2010 & increase $2008-10$ & number & length $[\mathrm{cm}]$ & & \\
\hline 'Isolda'/CPS & $21.4 \mathrm{de}^{*}$ & $14.1 \mathrm{c}$ & $90.9 \mathrm{c}-\mathrm{e}$ & $3047 \mathrm{f}$ & $4.0 \mathrm{fg}$ & $0.42 \mathrm{ab}$ \\
\hline 'Hortensia'/CPS & 21.6 de & $12.0 \mathrm{c}$ & $81.0 \mathrm{~cd}$ & $3185 \mathrm{f}$ & $4.4 \mathrm{~g}$ & $0.81 \mathrm{~cd}$ \\
\hline 'Fertilia'/CPS & $14.5 \mathrm{bc}$ & $8.7 \mathrm{~b}$ & $57.3 \mathrm{~b}$ & $1431 b$ & $2.6 \mathrm{c}$ & $1.25 \mathrm{ef}$ \\
\hline 'Morava'/Q1 & $9.5 \mathrm{a}$ & $4.9 \mathrm{a}$ & $28.6 \mathrm{a}$ & $631 \mathrm{a}$ & $1.3 \mathrm{a}$ & 0.99 de \\
\hline 'Morava'/CPS & $12.9 \mathrm{ab}$ & $7.0 \mathrm{ab}$ & $51.1 \mathrm{~b}$ & $1016 \mathrm{ab}$ & $1.9 \mathrm{~b}$ & $0.86 \mathrm{~d}$ \\
\hline 'Wyżnica'/CPS & $31.9 \mathrm{~g}$ & $19.2 \mathrm{~d}$ & $104.4 \mathrm{e}$ & 2485 de & $3.6 \mathrm{ef}$ & $0.93 \mathrm{~d}$ \\
\hline 'Nojabrskaja'/CPS & $22.1 \mathrm{e}$ & $11.9 \mathrm{c}$ & 94.3 de & $2268 \mathrm{~cd}$ & $2.7 \mathrm{~cd}$ & $1.41 \mathrm{f}$ \\
\hline 'Blanka'/Q1 & $18.9 \mathrm{de}$ & $11.9 \mathrm{c}$ & $31.8 \mathrm{a}$ & $843 \mathrm{a}$ & $2.1 \mathrm{~b}$ & $0.85 \mathrm{~d}$ \\
\hline 'Blanka'/CPS & $26.8 \mathrm{f}$ & $18.8 \mathrm{~d}$ & $37.0 \mathrm{a}$ & $1009 a b$ & $3.2 \mathrm{de}$ & $0.13 \mathrm{a}$ \\
\hline 'Uta'/CPS & $14.5 \mathrm{bc}$ & $8.9 \mathrm{~b}$ & $74.9 \mathrm{c}$ & $1976 \mathrm{c}$ & $3.1 \mathrm{~cd}$ & $1.46 \mathrm{f}$ \\
\hline 'David'/CPS & 20.6 de & $12.5 \mathrm{c}$ & $94.1 \mathrm{de}$ & 2747 ef & $2.9 \mathrm{~cd}$ & $0.50 \mathrm{bc}$ \\
\hline 'Bohemica'/Q1 & $18.0 \mathrm{~cd}$ & $12.8 \mathrm{c}$ & $41.0 \mathrm{ab}$ & $1062 \mathrm{ab}$ & $2.1 \mathrm{~b}$ & $0.51 \mathrm{bc}$ \\
\hline
\end{tabular}

* Explanations, see Table 1

\section{CONCLUSIONS}

1. Based on the 5-year study, it can be stated that 'Nojabrskaja' ('Xenia ${ }^{\circledR}$ ') and 'Wyżnica' pears proved to be the best for cultivation in the climatic conditions of Lower Silesia.

2. Considering the quantity and quality of yield, Caucasian pear seedlings were found to be the proper rootstock for the evaluated cultivars, with the exception for 'Blanka' pear. The low yields in some years were caused mainly by the climatic conditions, especially by spring frosts.

3. The type of rootstock had no significant effect on mean fruit weight. 'Blanka' fruits turned out to be too big for dessert purposes, which can be considered as a disadvantage of this cultivar.

\section{Acknowledgements}

This work was co-financed by the Project 'Enterprising Graduate Student - an investment in the innovative development of the region' (Human Capital Operational Programme, Priority VIII Regional Human Resources, Measure 8.2 Transfer of Knowledge, Sub-measure 8.2.2 Regional Innovation Strategies).

KAPITAŁ LUDZKI

NARODOWA STRATEGIA SPOJNOSCI

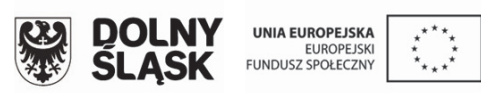

This work was co-financed by the European Union as part of the European Social Fund.

\section{REFERENCES}

Bielicki P., Czynczyk A. 2006. Przydatność różnych podkładek dla nowych odmian gruszy. Ogólnopolska Konferencja Nowe Odmiany Drzew Owocowych, Skierniewice 5 kwietnia: 33-40 (in Polish).

Bielicki P., Czynczyk A., Bartosiewicz B., Kruczyńska D. 2010. Wzrost i owocowanie gruszy odmiany Konferencja na różnych podkładkach. XLVI Ogólnopolska Naukowa Konferencja Sadownicza „Nauka Praktyce”, Skierniewice 29-30 września: 135-137. (in Polish)

Bielicki P., Czynczyk A., Kruczyńska D., Bartosiewicz B. 2008. Growth and yielding of some pear cultivars grafted on three rootstocks. Bulletin UASVM, Horticulture, 65(1): 504.

B lažek J., Vondráček J., Vávra R. 2003. Yield and tree vigour of pear cultivars bred in the RBIP at Holovousy. Vědeckě Práce Ovocnářské, 18: 39-51.

Castro H.R., Rodríguez R.O. 2002. The behavior of quince selections as pear rootstocks for 'Abate Fetel' and 'Conference' pear cultivars in the Rio Negro Valley, Argentina. Acta Hort. 596(1): 363-368.

Heijerman-Peppelman G., Bucarciuc V., Kemp H., Pasat O. 2009. 'Xenia', a new pear cultivar from Moldava, first results in The Netherlands. Acta Hort. 814(1): 305-308.

Kurlus R., Łysiak G. 1999. Nowe, obiecujące odmiany grusz i jabłoni z Techobuzic. VIII Spotkanie Sadownicze Sandomierz, 1999: 137-143 (in Polish). 
Kviklys D. 2005. Rootstock effect on Conference pear vegetative and generative development. Sodininkyst ir Daržininkyst , 24(2): 3-10.

Kviklys D., Kviklien N. 2005. Vegetative and seedling rootstock effect on pear fruit internal and external quality. Sodininkyst ir Daržininkyst , 24(2): 11-19.

Lewko L., Modrak P. 2009. Orchard performance of young 'Erika' pear trees depending on rootstock and root pruning. Zesz. Probl. Post. Nauk Rol. 536: 137-142. (in Polish)

Mohan Jain S., Priyadarshan P.M. 2009. Breeding Plantation Tree Crops: Temperate Species. Springer Science+Business Media: 135-161.

Paprštein F., Kloutvor J. 2005a. Winter cultivar of pear 'David'. Vědeckě Práce Ovocnářské, 19: 179-180.

Paprštein F., Kloutvor J. 2005b. Summer cultivar of pear 'Isolda'. Vědeckě Práce Ovocnářské, 19: 181-182.

Paprštein F., Matějíček A., Kloutvor J. 2007. Evaluation of summer pear cultivars. Nové odrůdy ovoce: $19-24$

S o sn a I. 2007. Uprawa gruszy. Plantpress, Kraków. (in Polish)

Sosna I., Czaplicka M. 2007. Ocena wartości produkcyjnej kilku nowych odmian gruszy na dwóch podkładkach. / Estimation of productive value of several new pear cultivars on two rootstocks. Rocz. AR Pozn. CCCLXXXIII, Ogrodn. 41: 383-388 (in Polish).

Stern R.A., Doron I., Ben-Arie R. 2007. Performance of 'Coscia' pear (Pyrus communis) on seven rootstocks in a warm climate. J. Hort. Sci. Biotech. 82(5): 798-802.

\section{Ocena kilku mniej znanych odmian gruszy (Pyrus communis L.) w warunkach klimatycznych Dolnego Śląska}

\author{
Streszczenie
}

Celem badań była ocena kwitnienia, plonowania, jakości owoców oraz wzrostu kilku mniej znanych odmian gruszy rosnących w warunkach klimatycznych Dolnego Śląska. Doświadczenie przeprowadzono w latach 2006-2010 w Stacji Badawczo-Dydaktycznej zlokalizowanej w miejscowości Samotwór, w okolicach Wrocławia. Wiosną 2006 roku posadzono drzewa kilku mniej znanych odmian gruszy: 'Isolda', 'Hortensia', 'Fertilia Delbard Delwilmor', 'Wyżnica', 'Nojabrskaja' ('Xenia ${ }^{\circledR}$ '), 'Uta', 'David' na gruszy kaukaskiej (Pyrus caucasica Fed.), 'Bohemica' na pigwie S1 (Cydonia oblonga Mill.), a 'Morava' i 'Blanka' na obu tych podkładkach. Istotnie najwyższą sumę plonu z lat 2007-2010 zanotowano dla odmian 'Nojabrskaja' i 'Wyżnica'. Największe owoce wytworzyła odmiana 'Blanka', natomiast najmniejsze 'Isolda'. Największy przyrost i pole przekroju poprzecznego pnia miały drzewa odmiany 'Wyżnica', a najmniejsze 'Morava', u której grubość pnia była podobna na obu zastosowanych podkładkach. Istotnie najmniejsze korony tworzyła odmiana 'Morava' uszlachetniona na pigwie S1. Natomiast do odmian wytwarzających największe korony należały 'Isolda' i 'Hortensia'. 